\title{
Цифровизация агропромышленного комплекса Дальнего Востока, как один из приоритетов государственной политики
}

Целью данного исследования является изучение особенностей развития цифровизации в агропромышленном комплексе Дальнего Востока как одного из приоритетов государственной политики Российской Федерации.

В рамках обозначенной цели основными задачами явились: систематизация теоретических основ исследования цифровизации агропромышленного комплекса, рассмотрение ключевых этапов и особенностей развития агропромышленного комплекса, исследование различных уровней оценки цифровизации агропромышленного комплекса, обзор наиболее значимых государственных инициатив и частных проектов в сфрере цифровизации агропромышленного комплекса.

Цифровизация, являющаяся одним из глобальных трендов современного мира, характеризуется стремительным развитием и проникновением цифрровых технологий в различные области человеческой жизнедеятельности. Многие страны мира постепенно входят в новый цивилизационный уклад, где цифровая доминанта становится важнейшим фрактором общественного развития, который приобретает фондаментальное значение для всех государств мира. Цифровизация определена одним из главных инструментов развития в Германии, в Китае, в США и других государствах мира. Российская Федерация не является исключением, так как в свою очередь объявила цифровизацию одним из приоритетов государственной политики, что установлено Указом Президента Российской Федерации от 21 июля 2020 г. № 474 "О национальных целях развития Российской Федерации на период до 2030 года", а также рассматривается как обязательное условие конкурентоспособности на современном глобальном рынке и стратегическая составляющая экономического суверенитета государства [37].

За короткое время в России были подготовлены основополагающие документы в сфрере цифровизации, такие как "Стратегия развития информационного общества в Российской Федерации на 2017-2030 гг.", национальный проект "Цифровая экономика" и программа "Цифровая экономика", а также ряд ведомственных проектов в различных секторах экономики и отдельных социальных сдерах.

В рамках осуществления намеченных планов, сформировано и функционирует Министерство цифрового развития, связи и массовых коммуникаций российской Федерации, которое осуществляет фуннции по выработке и реализации государственной политики и нормативно-правовому регулированию в сфрере формирования современной информационно-телекоммуникационной инфраструктуры, а также предоставление на её основе качественных услуг в сфере информационных технологий и обеспечение высокого уровня доступности для населения информации и технологий [18].

Создано и функционирует Правительственная комиссия по цифровому развитию, использованию информационных технологий для улучшения качества жизни и условий ведения предпринимательской деятельности. Данная Комиссия является координационным органом, задачей которого является обеспечение согласованных действий между ветвями власти Российской Федерации по разработке и реализации государственной политики, а также для обеспечения реализации задач в сфрере повышения уровня использова-

\author{
(C) Склярова С. А., 2021
}

СКЛЯРОВА Софья Андреевна, аспирант, ассистент кафедры международных отношений и права Владивостокского государственного университета экономики и сервиса (2. Владивосток). E-mail: sofya.sklyarova.96@mail.ru 
ния ИКТ в целях улучшения государственного управления и модернизации социальной сфреры [19].

Одной из наиболее сложных и перспективных задач для Российской Федерации является цифровизация агропромышленного комплекса Дальнего Востока. Необходимо отметить, что АПК определён одним из приоритетных секторов экспортно-ориентированной экономики, что отражено в Указе Президента "О национальных целях и стратегических задачах развития Российской Федерации на период до 2024 года", где главной задачей для агропродовольственной отрасли является наращивание объёмов экспорта до $\$ 45$ млрд к 2024 г. [38]. В посланиях Президента Российской Федерации Федеральному Собранию Российской Федерации также отражена задача о поставке на мировые рынки большего объёма продовольствия, чем ввозимого в страну, и повышение самообеспеченности страны продуктами питания. Ещё одной приоритетной задачей в агропромышленной сфере было обозначено создание защищённого бренда отечественной экологически чистой продукции, который должен подтверждать, что в её производстве используются только безопасные для здоровья человека технологии $[20 ; 21]$.

Значимость әффективного развития Агропромышленного комплекса для РФ, безусловно, формируется и глобальными трендами:

1. Изменение географической конфигурации глобального экономического влияния в пользу развивающихся опережающими темпами государств Восточной, Юго-Восточной и Южной Азии;

2. Ожидаемые демографические процессы, в соответствии с которыми прогнозируется увеличение населения планеты более чем на 1,5 млрд. при численности голодающих в мире около 1 млрд.;

3. Происходящие климатические изменения, в целом ухудшающие состояние природных комплексов $[17$, с. 12-15].

Цифровизация АПК во многом определяется одним из главных и перспективных инструментов государственной политики достижения задачи по наращиванию экспорта продовольствия, обеспечения продовольственной безопасности, а также инструментом, способным ответить на глобальный угрозы будущего, такие как изменения климата и стремительный рост населения мира.

\section{Теоретико-методологический анализ}

Необходимо определить, что в современной науке цифровизация агропромышленного комплекса рассматривается в основном экономистами с точки зрения экономических выгод, вносимых цифровыми технологиями в развитие отрасли. В этом направлении значимыми работами можно выделить труды А. И. Алтухова, М. К. Ашиновой, М. Л. Вартановой, Е. В. Дробот, Н. Н. Юриной, М. Анитей, У. Дейхманном и др $[1 ; 6 ; 7 ; 39 ; 41 ; 46]$.

Достаточно часто цифровизация АПК исследуется специалистами и международными организациями в качестве ответа на глобальные угрозы будущего, например, как изменение климата. Огромный вклад в изучение данных вопросов внесли Н. Трендов, Л. Хрустек, Т. Либберт, продовольственная и сельскохозяйственная организация ООН (FAO), Мировой банк [35; 43; 44].

Цифровизация АПК изучается в качестве значимого инструмента обеспечения глобальной и национальной продовольственной безопасности. В этом дискурсе значимый вклад внесли А. В. Курдюмов, Э. Н. Крылатых, Р. К. Арыкбаев, Р. А. Бахн [5; 12; 13; 40].

Перспективность развития АПК на Дальнем Востоке России обосновывается в работах Т. А. Потенко, А. Н. Емельянова и А. А. Степанько. Авторы указывают на экспортный потенциал АПК округа $[22 ; 28]$. Г. И. Сухомиров в своём исследовании обратил внимание, что технологическая модернизация сельского хозяйства способна решить проблемы в сельском хозяйстве Дальнего Востока и вывести отрасль региона на принципиально новый уровень, который будет соответствовать мировым стандартам [31].

Определение цифровизации агропромышленного комплекса приоритетом государственной политики характерно для Китайской Народной Республики. Согласно Центральному Документу № 1, а также плану развития сельского хозяйства на 2018-2024 гг. цифровизация АПК позволит решить вопросы национальной важности, такие как "возрождение деревни", обеспе- 
чение продовольственной безопасности государства и экологические (засуха, исчерпание водных и земельных ресурсов) [16].

В Стратегии Устойчивого развития Германии в главе С "вклад Германии в цели достижения ЦУР" акцентируется внимание на том, что цифровизация агропромышленного комплекса вносит значительный вклад в обеспечение мира качественным продовольствием и в связи с этим данные процессы поддерживаются и продвигаются на территории немецкого государства. В Стратегии цифровая трансформация в сельском хозяйстве обозначается важным инструментом для решения стратегических задач в Германии, таких как изменение климата, сокращение пахотных земель и сокращение природных ресурсов необходимых для әффрективного сельскохозяйствыенного производства [42, p. 139-141].

В Стратегии инновационного развития сельского хозяйства США отмечается, что цифровизация сельского хозяйства отвечает национальной цели о сохранении лидерства США на сельскохозяйственном рынке, а также целям обеспечения качественной и безопасной продукцией растущего населения страны [45, p. 1-5].

Для Российской Федерации цифровизация агропромышленного комплекса могла бы послужить решением для таких задач, как развитие не ресурсного экспорта и выхода на лидирующие позиции на мировом продовольственном рынке, обеспечение продовольственной безопасности и сувернитета государства, обеспечение социально-экономической стабильности. В этом ключе свою значимость приобретают территории Дальневосточного Федерального округа.

\section{Исторические аспекты развития АПК на Дальнем Востоке России}

Для России Дальний Восток ещё с середины XIX в. имел статус стратегически важной территории. Во многом это определялось угрозой со стороны граничащих с территориями Дальнего Востока стран. Активное развитие агропромышленного комплекса на Дальнем Востоке наблюдается в период pedopм П.А. Столыпина. Развитие АПК происходило в рамках переселенческой политики на Дальний Восток. Переселенцам предоставлялись ссуды на приобретение земли, льготные кредиты на приобретение, как отечественной, так и зарубежной техники. Также государством предоставлялась агрономическое содействие. Агрономические мероприятия включали в себя организацию опытных посевов, оборудование метеорологических станций, проведение обследования хозяйств и др. В Департаменте земледелия была учреждена агрономическая организация, современным аналогом которой являются информационные сельскохозяйственные агентства. Служащими организации оказывалось информирование о посеве и сборе урожая, оказывалась помощь населению в использовании сельскохозяйственных орудий и машин, организация опытов на опытно-показательных участках [11, с. 226-231].

Данные мероприятия, а также активное внедрение и использование сельскохозяйственной техники, обеспеченное льготными государственными кредитами и развивающимся кооперативным движением, использование дешёвого иностранного труда, заимствование опыта земледелия корейских и китайских крестьян, давно проживавших на территориях Дальнего Востока, а также удобная форма арендного землевладения оказали сильное влияние на развитие агропромышленного комплекса региона.

Результатами стали высокие темпы роста посевных площадей. С 1907 по 1910 гг. среднегодовой прирост составил $17 \%$, а в следующие семь лет 9,2 $\%$. Рост урожая увеличивался за счёт интенсификащии сельскохозяйственного производства. Дальний Восток стал основным производителем хлеба в Восточной Сибири и мог полностью обеспечить независимость от импортного продукта [14, с. 21-25].

В 1920-1930 гг., на развитие сельского хозяйства на Дальнем Востоке сильное влияние оказала государственная политика Советского Союза. Советская власть проводила на Дальнем Востоке политику, основанную на принципах "развития самодеятельности окраин, достижения ими самоокупаемости и независимости от внешних рынков". Агропродовольственная политика была нацелена на развитие собственного зернового производства и 
достижение самообеспечения региона хлебом. Первостепенной задачей в 1922-1924 гг. являлось сокращение импорта продовольствия [27, с. 92].

Дальний Восток ещё во время Второй мировой войны был стратегически важен и данный статус закрепился и в конце 1960-х гг., когда стала нарастать напряжённость на границе с Китаем. Первостепенной задачей для Дальневосточных территорий было самообеспечение региона основными продуктами питания в силу сильной зависимости региона от поставок продовольствия из Сибири, Урала и Центральной России, что было отражено в постановлении ЦК КПСС и Совмина СССР от 8 июля 1967 г. № 368 (ГААО. Ф. П-63. Оп. 2. Д. 415. Л. 4. Рукопись Ващук А.С.) ${ }^{1}$

Решением продовольственной проблемы на Дальнем Востоке являлось сочетание механизации и увеличение тружеников в сфере сельского хозяйства. Властями предусматривалось переселение в Амурскую область, Хабаровский и Приморский край. Для переселенцев предоставлялись пособия, их наделяли жильём, скотом и земельными участками, а также были введены налоговые послабления. За счёт данных мер кризис удалось преодолеть. В этот период были созданы новые совхозы, построены птицефабрики в с. Некрасовка Хабаровского района, в Николаевске-на-Амуре, Охотске, Советской Гавани, Комсомольске-на-Амуре, крупнейший на всем Дальнем Востоке молочный комбинат в с. Черная Речка, Лазовский молочный и Хорский откормочный комплекс и др. Для улучшения снабжения жителей края свежими овощами в Хабаровске, Комсомольске-на-Амуре, Амурске были созданы тепличные комбинаты. Основной курс на сооружение крупных механизированных сельскохозяйственных предприятий не менялся.

В 1980-е гг. по всем регионам ДФО наблюдался значительный рост производства мяса, молока и яиц, в меньшей степени - зерна и картофеля за счет вложения больших государственных средств в сельское хозяйство Дальнего Востока. Однако темпы сельскохозяйственного производства стали снижаться, а ко второй половине 1980-х гг. в регионе снова стали нарастать кризисные явления. В результате к концу 1980-х гг. сельское хозяйство Дальнего Востока не смогло обеспечить население региона продуктами питания местного производства [30, с. 93].

В 1990-е гг. и в начале 2000-х гг. на развитие сельского хозяйства сильное влияние оказали социально-экономические реформы. На Дальнем Востоке произошло резкое сокращение посевов, поголовья крупного рогатого скота, свиней и птиц. В результате к 2005 г. сократилось производство зерновой, мясной и молочной продукции, а также яиц. Самообеспеченность региона даже в условиях оттока населения снижалась.

После 2005 г. аграрная политика в Дальневосточном регионе была нацелена на повышения качества жизни в сельской местности и более интенсивное развитие сельского хозяйства. В субъектах региона были разработаны программы развития сельского хозяйства, которые содержали такие меры, как установление налоговых льгот для сельхозпроизводителей, регулирование уровня арендной платы за землю, предоставление бюджетных средств сельскохозяйственным производителям, научным организациям и др., предоставление консультационной помощи аграриям, развитие социальной инфрраструктуры, субсидирование части кредитов и др.

Стабильная экономическая ситуация, а также реализованные меры привели к росту показателей в сфере растениеводства и животноводства в 2014 г. Посевные площади увеличились с 1223,8 тыс. га до 1787,7 тыс. га. Особенно сильно увеличился показатель производства сои с 436,6 тыс. тонн до 1527,1 тыс. тонн в эти же годы [32, с. 177].

На современном этапе территории Дальнего Востока не потеряли своей стратегической значимости. Кроме важной роли в сфере национальной безопасности, Дальний Восток является приоритетным направлением развития в рамках концепции "поворота на Восток". И агропромышленный комплекс играет значимую роль в развитии социально-экономического уровня дальневосточных территорий.

1 ГААО - Государственный архив Амурской области 
Экспортный потенциал агропромышленного комплекса во многом связан с конкурентными преимуществами Дальнего Востока перед другими регионами России, такими как:

1. Логистическая доступность к рынкам Азиатско-Тихоокеанского региона;

2. Природно-ресурсный потенциал (земельные и водные ресурсы). Природно-ресурсный потенщиал позволяет выращивать сою, основной спрос на которую формируется Китайской Народной Республикой. Немаловажную роль играет и природно-ресурсный потенциал в формировании предложения на спрос экологически чистой продукщии как стран Азиатско-Тихоокеанского региона, так и Европейских стран [22, с. 127; 29, с. 71].

Специфика современной политики развития АПК, в частности сельского хозяйства Дальнего Востока, состоит в том, что она ориентирована на внутрирегиональное потребление с экспортным производством узкого перечня видов продукции, что соответствует целевым установкам современной аграрной политики: ориентация на наращивание сельскохозяйственного экспорта и импортозамещение [3, с. 25].

Для обеспечения поставленных задач осуществляется отраслевая политика, которая представлена в документах "Развитие сельского хозяйства и регулирование рынков сельскохозяйственной продукции сырья и продовольствия", разработанных каждым из субъектов Дальневосточного Федерального округа с учётом их специфики. В программе содержатся меры содействия развитию: выделение субсидий на закупку семян, на культуртехнические мероприятия, на возмещение части затрат на проведение посевных работ, на приобретение современной техники, предоставление грантов на развитие семейных молочных животноводческих ферм, на развитие крестьянских фрермерских хозяйств, создание условий для научного обеспечения развития сельскохозяйственного производства в виде субсидий и грантов и др.

Также в настоящее время на развитие сельского хозяйства оказывают влияние и государственные меры развития экономики Дальнего Востока, к которым можно отнести территории опережающего развития, резидентами которых являются в основном сельскохозяйственные компании, как отечественные, так и зарубежные [3, с. 28].

Одним из значимых инструментов развития агропромышленного комплекса на современном этапе является цифровизация, что отмечено в опубликованной стратегии развития агропромышленного и рыбохозяйственного комплексов Российской Федерации на период до 2030 г., а также в Федеральной программе научно-технического развития сельского хозяйства на 20172025 гг. [24].

\section{Уровень цифровизации АПК Дальнего Востока в государственных и иных оценках}

Цифровизация АПК - это многогранный процесс, который включает в себя множество фракторов. Можно оценивать, как общий уровень цифровизации, учитывая готовность кадров, внедрение цифровых технологий, развитие интернет-инфраструктуры и др., так и оценку по каждому направлению технологий. В 2020 г. Центром прогнозирования и мониторинга Кубанского ГАУ совместно с Департаментом научно-технологической политики и образования Министерства сельского хозяйства РФ был опубликован рейтинг использования элементов точного земледелия в регионах РФ. Рейтинг был составлен на основе данных, полученных из 64 регионов по точному земледелию и 68 регионов по точному животноводству по количеству хозяйств, использующих данную технологию [36]. В рамках данного исследования необходимо сопоставить результаты по Центральному федеральному и Дальневосточному округам для сравнения максимальных и минимальных значений. Результаты представлены в таблице 1.

В данном рейтинге отражены 7 субъектов Дальневосточного федерального округа. В первой десятке находится Амурская область. Приморский край, Хабаровский край, Республика Бурятия и Забайкальский край имеют низкие показатели. Сахалинская область, согласно данному рейтингу, не использует технологии точного земледелия. В сравнении очевидно сильное отставание Дальнего Востока от центральной России. 
Табл. 1. Количество хозяйств, использующих технологии точного земледелия в ЦФО и ДФО в 2018-2019 гг.

\begin{tabular}{|l|c|l|c|}
\hline \multicolumn{1}{|c|}{ Субъект ЦФФО } & Кол-во хозяйств & \multicolumn{1}{c|}{ Субъект ДФО } & Кол-во хозяйств \\
\hline Воронежская область & 211 & Амурская область & 102 \\
\hline Орловская область & 112 & Приморский край & 12 \\
\hline Тамбовская область & 110 & Хабаровский край & 7 \\
\hline Белгородская область & 75 & Еврейский автономный округ & 3 \\
\hline Тульская область & 46 & Республика Бурятия & 3 \\
\hline Брянская область & 44 & Забайкальский край & 1 \\
\hline Рязанская область & 35 & Сахалинская область & 0 \\
\hline
\end{tabular}

Источник: составлено на основе: [36, с. 9-10].

Согласно такому же рейтингу в сфере животноводства, ни один из регионов Дальнего Востока не занимает лидирующие позищии. Так, на первом месте находится Удмуртская Республика, где 123 хозяйства используют технологии точного земледелия и на 33 месте находится Республика Бурятия, где только 15 хозяйств используют данные технологии [36, с. 21-22].

В 2020 г. центр развития фринансовых технологий Россельхозбанка составил рейтинг готовности субъектов РФ к внедрению цифровых технологий в сельском хозяйстве. Оценка проводилась в рамках анализа перспектив внедрения умного животноводства и точного земледелия на территории субъектов РФ. Для составления данного рейтинга специалистами были проанализированы такие показатели, как обеспеченность кадрами и их подготовка, технические возможности (покрытие сетями для внедрения технологии "Интернета вещей"), количество документов, обеспечивающих поддержку внедрения технологий, процент предприятий, использующих цифровые решения. В рейтинге субъекты были разделены на четыре группы. В первую группу попали 10 субъектов, которые согласно проведённой оценке полностью готовы к внедрению цифровых технологий в сельское хозяйство. В данный список вошли Краснодарский край, Новосибирская область, Башкирия, Воронежская, Тамбовская, Челябинская, Нижегородская, Белгородская области, а также Омская и Архангельская области.

Во вторую группу вошли 15 субъектов с хорошим уровнем готовности к внедрению технологий точного земледелия и умного животноводства. Специалисты отметили высокий уровень подготовки кадров для сельского хозяйства, а также готовность инфраструктуры и низкий процент предприятий, использующих цифровые технологии, а также недостаточное количество программ поддержки.

Субъекты Дальневосточного Федерального округа вошли в две последние группы, где только ведётся работа над созданием условий для внедрения циорровых технологий в сельское хозяйство [9].

Согласно первой оценке Амурская область находилась на лидирующих позициях, тем не менее вторая оценка не показала такого же результата за счёт подключения к оценке дополнительной информации, что указывает на проблемы в сфере подготовки и переквалификащии кадров, занятых в сельском хозяйстве, слабую государственную поддержку и слаборазвитую инфраструктуру, необходимую для внедрения технологий точного земледелия и умного животноводства.

Министерством сельского хозяйства РФ в 2019 г. проводилась оценка уровня цифровизации АПК в регионах в целом. В ходе исследования учитывались такие показатели, как применение цифровых технологий, создание специальных нормативных правовых актов и внесение в них изменений для обеспечения реализации ведомственного проекта "Цифровое сельское хозяй- 
ство", апробации пилотных проектов в сфрере цифровизации агропромышленного комплекса.

Самые низкие темпы цифровизации были зафиксированы в Еврейской автономной области, Амурской, Кировской, Костромской, Магаданской и Мурманской областях, Камчатском и Приморском краях, Кабардино-Балкарской и Карачаево-Черкесской республиках [8].

Необходимо заметить, что Министерством сельского хозяйства РФ разработаны методические рекомендации для вычисления регионального индекса цифрровизации агропромышленного комплекса. Расчёт предполагается производить на основе системы показателей четырёх интегрируемых субиндексах: субиндекс 1 (уровень развития цифровых технологий производителя продовольствия), субиндекс 2 (уровень развития технической инфраструктуры), субиндекс 3 (уровень развития трудовых ресурсов), субиндекс 4 (уровень развития информационной инфраструктуры АПК субъекта РФ, на территории которого осуществляется деятельность производителя сельскохозяйственной продукции и продовольствия). В данных рекомендациях в качестве субиндекса не рассматривается создание специальных нормативных актов и программ поддержки, а также апробации пилотных проектов в агропромышленном комплексе [4, с. 25-26].

Однако, по мнению автора, рассмотренные выше методики и рекомендации не являются объективными, так как не учитывают региональные особенности, в частности, участие бизнеса (инвестиций) в цифровизации агропромышленного комплекса региона. Кроме того, при оценке не учитывается количество агрохолдингов и некрупных фермерских хозяйств в каждом из регионов, так как внедрение технологий для агрохолдингов значительно доступнее, чем для небольших фрермерских и крестьянских хозяйств.

\section{Значимые государственные инициативы и частные проекты в сфере цифровизации агропромышленного комплекса}

Низкая оценка готовности к внедрению цифровых технологий в Агропромышленный комплекс региона, а также зафиксированные в 2019 г. медленные темпы цифровизации не означают отсутствие любых процессов в этой сфере. Цифровизация - это многоуровневый процесс, который включает в себя как использование цифровых технологий на поле (Интернет вещей, специальные датчики, искусственный интеллект др.), технологии для предоставления информации о сборе, посадке, удобрении, продаже и пр. в виде специальных платформ ("Цифровое сельское хозяйство"), а также использование технологий интернета для развития электронной коммерции в сельской местности.

В Китайской Народной Республике одним из важных приоритетов цифровизации в агропромышленном комплексе обозначено развитие электронной коммерции. В рамках государственной программы "Интернет+" онлайн-продажи сельскохозяйственной продукции способствуют обогащению сельского населения, занятого в сфере сельского хозяйства, а также отвечают запросам потребителя на более дешёвую органическую и безопасную продукцию, в силу исключения посредников. В свою очередь, в Российской Федерации Россельхозбанком разработана онлайн-площадка "Своё, родное" для торговли фермерами продукцией собственного производства. Анализ показал, что в районе крупных городов субъектов Дальневосточного Федерального округа зарегистрировано около двухсот фермерских хозяйств, предлагающих к продаже продукцию собственного производства. Разбивка по регионам представлена в таблице 2.

Не менее значимым инструментом цифровизации является создание региональных специализированных платформ по предоставлению цифровых сервисов, которые обеспечивают государственную поддержку в электронном виде. Государственная поддержка является важным әлементом устойчивого развития сельского хозяйства в регионах. Внедрённая цифровая платформа ИС РЕСПАК в 15 субъектах РФ, в том числе в Сахалинской и Иркутской областях, а также в Забайкальском крае позволяет сельхозпроизводителям без личного визита обратиться за государственной поддержкой, что ускоряет процесс и минимизирует издержки [10].

Маркировка молочной продукции, также является важной составляющей цифровизации в сельском хозяйстве. Маркировка обеспечивает и га- 
Табл. 2. Количество зарегистрированных фермерских хозяйств в онлайн-маркете Россельхозбанка "Своё, родное" по состоянию на 2021 год

\begin{tabular}{|l|l|c|}
\hline \multicolumn{1}{|c|}{ Субъект федерации } & \multicolumn{1}{c|}{ Город } & Кол-во зарегистрированных фермеров \\
\hline Приморский край & Владивосток & 25 \\
\hline Хабаровский край & Хабаровск & 24 \\
\hline Забайкальский край & Иркутск & 43 \\
\hline Камчатский край & Петропавловск-Камчатский & 54 \\
\hline Сахалинская область & Южно-Сахалинск & 22 \\
\hline Еврейская автономная область & Биробиджан & 24 \\
\hline
\end{tabular}

Источник: составлено на основе [26].

рантирует безопасность продовольствия. По состоянию на 5 августа 2021 г. 2135 компаний Дальнего Востока по производству молочной продукции зарегистрировались на национальной платформе цифровой маркировки "Честный знак" [23].

Стоит отметить и ряд крупных реализующихся проектов в сфрере цифровизации агропромышленного комплекса на Дальнем Востоке Российской Федерации. В 2018 г. компания Tele 2 заявила о планах запуска пилотного проекта по цифровизации ферм, выращивающих аквакультуру в Приморском крае. Весной 2019 г. в рамках данного проекта на нескольких марифермах в Приморском крае были установлены цифровые датчики, которые измеряют физические и гидрохимические параметры воды - температуру, кислотность, соленость и насыщенность кислородом. Морские гидробионты - устрицы, гребешки, трепанги чувствительны к этим параметрам, и их изменения могут повлиять на состояние популяции. Информация с датчиков поступает dермерам через мобильную сеть в режиме реального времени. Цифровой подход, по данным компании, повышает качество и выживаемость марикультуры на 20-30\%. После апробации данного проекта компания в 2020 г. заявила о готовности распространения цифровых решений и на другие регионы Дальнего Востока. Компания Tele 2 не распространяет информацию, какие компании воспользовались данным сервером помимо компании "Дальстам-Марин", которая находится в бухте Воевода на Русском острове, ссылаясь на коммерческую тайну [34].

Не менее значимым проектом в сфрере цифровизации АПК является цифровизация предприятий группы компаний "Агротек" на Дальнем Востоке. Цифровые решения предоставила компания ПАО "Ростелеком". В рамках данного проекта на базе предприятий агрохолдинга были внедрены сервис видеонаблюдения для контроля процессов производства и комплексная система управления агробизнесом для организации и контроля за полевыми работами, которая способна вести учёт урожая и спрогнозировать потери. Данная система анализирует информацию и предоставляет отчёт в виде графиков и таблиц, что позволяет вести учет операций и контролировать полевые работы в реальном времени. Таким образом, комплексная система управляет производственными процессами на всех этапах и контролирует әфреективность обработки полей. Также ПАО "Ростелеком" планируется внедрение на базе агрохолдинга "Агротек" технологии телеметрического зрения в сфрере животноводства, которая позволит отслеживать здоровье животных, прогнозировать объём продукции [25].

В Хабаровском крае на базе сельскохозяйственного производственного кооператива "Благодатное" запущена система цифрового управления молочной фермой на основе технологии "Интернета вещей". Разработчиком данного решения выступила компания МТС. С помощью установленных в желудок коров датчиков представляется возможность отслеживания состояния здоровья животных, прогнозировать наступление половой охоты и др. Специалистами 
прогнозируется, что при использовании данных технологий әффективность фермы повысится на 15-20\% [15].

В Дальневосточном Федеральном округе осуществляются и другие проекты в сфере цифровизации Агропромышленного комплекса, однако рамки статьи не позволяют включить обзор всех проектов.

Другой немаловажной составляющей в сфере цифровизации АПК являются программы государственной поддержки, а также планы и стратегии.

На национальном уровне Министерством сельского хозяйства РФ разработан проект "Цифровое сельское хозяйство". В рамках проекта предусмотрен комплекс мероприятий по внедрению цифровых технологий и платформенных решений в АПК. Проект содержит ряд общих указаний, таких как создание и внедрение специальных цифровых платформ, создание в регионах экспериментальных ферм (пилотных площадок), разработка системы обеспечения операционной деятельности и внедрения комплексных цифровых решений, создание подсистем "Комплексные цифровые решения для АПК" с элементами интернета вещей (IoT), самообучения и роботизации рутинных процессов, "Умная ферма", "Умное поле", "Умное стадо", проведение переквалификации работников в сфрере сельского хозяйство и др.

Также Правительственной комиссией по цифровому развитию, использованию информационных технологий для улучшения качества жизни и условий ведения предпринимательской деятельности утверждена стратегия цифровой трансформации сельского хозяйства "Привет, ферма" в 2021 г. [29].

Стоит отметить, что стратегии цифровой трансформации АПК субъектов Дальневосточного Федерального округа ещё находятся в разработке и по официальным данным должны быть опубликованы 1 сентября 2021 г.

На региональном уровне, как и замечено в вышерассмотренных оценках создано недостаточное количество программ государственной поддержки цифровизации АПК в субъектах ДФО. Во всех субъектах сельхозпроизводители могут воспользоваться субсидиями в рамках государственной программы "Развитие сельского хозяйства и регулирование рынков сельскохозяйственной продукции, сырья и продовольствия". В подпрограммах "Техническая и технологическая модернизация агропромышленного комплекса" предлагается субсидирование для приобретения высокотехнологичных машин и оборудования.

Анализ информации с сайта Министерства сельского хозяйства субъектов ДФО показал, что во всех субъектах, кроме Еврейской автономной области, отсутствуют программы поддержки, направленные на цифровизацию агропромышленного комплекса. В Еврейской автономной области создана специальная программы государственной поддержки в сфере цифровизации "Цифровая промышленность", в рамках которой предусмотрено предоставление заемного софинансирования на реализацию проектов, направленных на внедрение цифровых и технологических решений.

Стоит оговориться, что министерством сельского хозяйства определены пилотные регионы на территории которых планируется тестирование работы цифровой платформы "Цифровое сельское хозяйство", а также внедряться на производства цифровые технологии и роботы. Однако ни один из субъектов Дальневосточного Федерального округа не включён в данный перечень из 15 регионов [2].

Согласно опубликованному Аналитическим центром при правительстве Российской Федерации документу "Текущее развитие проектов в сфрере цифровой экономики в регионах России" в 2019 г. сельское хозяйство определено приоритетной областью в сфере цифровизации только в Камчатском крае и в Республике Бурятия. Кроме того, из представленных в документе проектов субъектами округа не отражены проекты и результаты по цифровизации сельского хозяйства [33]. 


\section{Заключение}

Дальний Восток во все времена являлся территорией стратегической важности, и поэтому на всех исторических этапах развитие АПК региона путём интенсификации производства занимало первостепенное значение. Современный курс России на повышение нересурсного экспорта, на усиление экономических и политических позиций в АТР, развитие сельских территорий и на обеспечение социально-экономической стабильности форммирует необходимость применения цифровых решений в регионе для ускорения и эффрективности достижения амбициозных целей государственной политики.

Цифровизация агропромышленного комплекса Дальневосточного dpeдерального округа могла бы стать приоритетом государственной политики в среднесрочной перспективе. Однако согласно исследованным оценкам, данных на различных уровнях, а также изучение и систематизация государственных и частных инициатив, представленных различными проектами в сфере цифровизации АПК региона, можно заключить, что на современном этапе существует ряд проблем, сдерживающих цифровизацию в агропромышленном комплексе региона, таких как отсутствие региональной стратегии и программ поддержки цифровизации в аграрной сфрере, слабо подготовленная инфраструктура для внедрения цифровых технологий, недостаточное информирование фрермеров о преимуществе использования современных технологий, слабое государственное управление данными процессами. Для достижения государственных целей необходима разработка не только стратегических, но и тактических мер цифровизации АПК, специально ориентированных на дальневосточный регион.

\section{Литература}

1. Алтухов А.И., Дудин М.Н., Анищенко А.Н. Цифровая трансформация как технологический прорыв и переход на новый уровень развития агропромышленного сектора России // Продовольственная политика и безопасность. 2020. Том 7. № 2. С. 8196.

2. Аналитический центр Минсельхоза России подписал соглашение о сотрудничестве с регионами страны // Министерство сельского хозяйства Российской Федерации. [Электронный ресурc]. URL: https://mcx.gov.ru/press-service/news/analiticheskiytsentr-minselkhoza-rossii-podpisal-soglashenie-o-sotrudnichestve-s-15-regionami-stran/ (дата обращения: 9.08.2021 г.).

3. Антонова Н.А. Влияние современной федеральной политики на развитие экспортного потенциала сельского хозяйства Дальнего Востока // Регионалистика. 2018. № 4. C. 24-34.

4. Архипов А.Г., Косогор С.Н., Буланов Н.А. Методические рекомендации по разработке регионального индекса цифровизации агропромышленного комплекса. М.: Министерство сельского хозяйства, 2019. 116 с.

5. Арыкбаев Р.К., Айтпаева А.А. Управление цифровизацией АПК и обеспечение продовольственной безопасности РФ в современных условиях // Влияние новой геополитической реальности на государственное управление и развитие Российской Федерации / под ред. З.А. Саидова. Грозный: Издательство ЧГУ, 2019. С. 52-56.

6. Ашинова М.К., Мокрушин А.А., Чиназирова С.К., Костенко Р.В. Цифровая трансформация отрасли сельского хозяйства Российской Федерации // Новые технологии / New technologies. 2019. № 4. C. 209-220.

7. Вартанова М.Л., Дробот Е.В. Перспективы цифровизации сельского хозяйства как приоритетного направления импортозамещения // Экономические отношения. 2018. Том 8. № 1. С. 1-18.

8. В половине регионов России отмечается положительная динамика цифровизации АПК // Министерство сельского хозяйства Российской Федерации. [Электронный ресурс]. URL: https://mcx.gov.ru/press-service/news/v-polovine-regionov-rossiiotmechaetsya-polozhitelnaya-dinamika-tsifrovizatsii-apk/ (дата обращения: 5.08.2021)

9. В Россельхозбанке назвали наиболее готовые к цифровому АПК регионы // РИА Новости. 19.06.2020. [Электронный ресурс]. URL: https://ria.ru/20200619/1573163101. html (дата обращения: 1.08.2021).

10. Господдержка фермеров переходит на цифру // Comnews. 1.09.2020. [Электронный pecypc]. URL:https://www.comnews.ru/content/208865/2020-09-01/2020-w36/ gospodderzhka-fermerov-perekhodit-cifru (дата обращения: 12.08.2021). 
11. Зуева Н.С. Переселенческая политика российского правительства на Дальнем Востоке в период столыпинских реформ. Дис.... канд. ист. наук. М.: Московский педагогический государственный университет, 2016. $351 \mathrm{c.}$

12. Крылатых Э.Н., Проценко О.Д., Дудин М.Н. Актуальные вопросы обеспечения продовольственной безопасности России в условиях глобальной цифровизации // Продовольственная политика и безопасность. 2020. Том 7. № 1. С. 19-38.

13. Курдюмов А.В. Реиндустриализация и цифровизация АПК России: основа обеспечения продовольственной безопасности // Новая индустриализация России: экономика - наука - человек - природопользование: сб. науч. тр. VI Уральских научных чтений профрессоров и докторантов. Екатеринбург: Уральский государственный экономический университет, 2019. С. 65-70.

14. Морозов Б.Н. Развитие сельского хозяйства, промышленности и промыслов на Дальнем Востоке России в конце XIX - начале XX веков. Авторефрерат дис.... д-ра. ист. наук. Нижний Новгород, 1997. 61 с.

15. На Дальнем Востоке запущена первая система цифрового управления молочной фермой на основе IоT датчиков от МTC // MTC. 4.06.2020. [Электронный pecypc]. URL: https://khv.mts.ru/about/media-centr/soobshheniya-kompanii/ novosti-mts-v-regione/2020-06-04/na-dalnem-vostoke-zapushhena-pervaya-sistemacifrovogo-upravleniya-molochnoj-fermoj-na-osnove-iot-datchikov-ot-mts (дата обращения: 12.08.2021).

16. Национальный план развития сельскохозяйственных и технологических парков (2018-2025) // Энциклопедия Baidu. [Электронный ресурc]. URL: https://goo. su/0zAc (дата обращения: 17.07.2021).

17. О долгосрочной стратегии развития агропромышленного комплекса Российской Федерации / Совет Федерации РФ. Аналитический вестник. 2018. №10 (699).

18. Постановление Правительства РФ от 02.06.2008 № 418 (ред. от 19.06.2021) «О Министерстве цифрового развития, связи и массовых коммуникаций Российской Федерации» // КонсультантПлюс. [Электронный ресурc]. URL: http://www.consultant.ru/ document/cons_doc_LAW_77387/ (дата обращения: 26.06.2021).

19. Постановление Правительства РФ от 07.09.2018 № 1065 (ред. от 24.07.2021) "О Правительственной комиссии по цифровому развитию, использованию информационных технологий для улучшения качества жизни и условий ведения предпринимательской деятельности" (вместе с "Положением о Правительственной комиссии по цифровому развитию, использованию информационных технологий для улучшения качества жизни и условий ведения предпринимательской деятельности") // КонсультантПлюс. [Электронный ресурc]. URL: http://www.consultant.ru/document/cons_doc_ LAW_306391/ (дата обращения: 24.07.2021).

$2 \overline{0}$. Послание Президента РФ Федеральному Собранию от 21.04.2021 // КонсультантПлюс. [Электронный ресурс]. URL: http://www.consultant.ru/document/cons_doc_ LAW_382666/ (дата обращения: 27.07.2021).

21. Послание Президента РФ Федеральному Собранию от 20.02.2019 // КонсультантПлюс. [Электронный ресурс]. URL: http://www.consultant.ru/document/cons_doc_ LAW_318543/ (дата обращения: 27.07.2021).

$2 \overline{2}$. Потенко Т.А., Емельянов А.Н. Экспортный потенциал сельского хозяйства Дальнего Востока России // Дальневосточный аграрный вестник. 2018. №1 (45). C. $125-133$.

23. Почти 600 молочных производителей честны с потребителем в Приморье // Честный знак. 5.08.2021. [Электронный ресурc]. URL: https://xn--80ajghhoc2aj1c8b. xn--p1ai/info/smi_o_nas/pochti-600-molochnykh-proizvoditeley-chestny-s-potrebitelem-vprimore/ (дата обращения: 12.08.2021).

24. Распоряжение Правительства РФ от 12.04.2020 N 993-р «Об утверждении Стратегии развития агропромышленного и рыбохозяйственного комплексов Российской Федерации на период до 2030 года» // КонсультантПлюс. [Электронный ресурс]. URL: http://www.consultant.ru/document/cons_doc_LAW_350437/ (дата обращения: 25.07.2021).

25. «Ростелеком» цифровизирует предприятия агрохолдинга «Агротек» // Ростелеком. 26.01.2021. [Электронный pecypc]. URL:https://www.company.rt.ru/press/news/ d457947/ (дата обращения: 12.08.2021).

26. Своё, родное: [сайт]. URL: https://svoe-rodnoe.ru/

27. Стасюкевич C.M. Земельная политика советской власти и землеустройство на Дальнем Востоке в 1920-х гг. // Ойкумена. Регионоведческие исследования. 2017. № 1(40). C. $90-103$.

28. Степанько А.А. Агропотенциал Дальнего Востока России и его использование в условиях продовольственных санкций // Вестник АГАУ. 2017. № 10 (156). С. 71-76.

29. Стратегия цифровой трансформации сельского хозяйства - «Моя цифровая ферма» или «Привет, Ферма!» (утв. Правительственной комиссией по цифровому развитию, использованию информационных технологий для улучшения качества жизни и условий ведения предпринимательской деятельности (протокол от 25.06.2021 № 20 
// КонсультантПлюс. [Электронный ресурс]. URL: http://www.consultant.ru/document/ cons_doc_LAW_390530/ (дата обращения: 28.06.2021).

30. С Срельцова Т.А. История развития сельского хозяйства Дальнего Востока (середина 1940-х - конец 1980-х гг.) // Дальневосточный аграрный вестник. 2008. №2 (6). C. 89-93.

31. Сухомиров Г.И. Технологическая модернизация сельского хозяйства Дальнего Востока // Проблемы развития территории. 2014. №5 (73). С. 123-135.

32. Сухомиров Г.И. Проблема самообеспечения сельскохозяйственными продуктами в регионах Дальневосточного федерального округа // Проблемы развития территории. 2017. №1 (87). С. 173-186.

33. Текущее развитие проектов в сфере цифровой экономики в регионах России // Аналитический центр при правительстве Российской Федерации. [Электронный pecypc]. URL: https://ac.gov.ru/archive/files/publication/a/23299.pdf (дата обращения: 20.07.2021).

34. Tele2 развивает «умную» марикультуру на Дальнем Востоке // Газета.ru. 6.06.2019. [Электронный pecypc]. URL: https://www.gazeta.ru/tech/ news/2019/06/06/n_13061359.shtml (дата обращения: 12.08.2021).

35. Трендов Н.М., Варас С., Цзэн М. Цифровые технологии на службе сельского хозяйства и сельских районов. Справочный документ. Рим: Продовольственная и сельскохозяйственная организация Объединенных Наций, 2019. 26 с.

36. Труфляк Е.В. Рейтинг регионов по использованию элементов точного сельского хозяйства. Краснодар: КубГАУ, 2020. 37 с.

37. Указ Президента Российской Федерации от 21 июля 2020 г. № 474 «О национальных целях развития Российской Федеращии на период до 2030 года» // Российская газета. 22.07.2020. [Электронный ресурc]. URL: https://rg.ru/2020/07/22/ukaz-dok.html (дата обращения: 14.08.2021).

38. Указ Президента Российской Федерации от 7 мая 2018 г. № 204 «О национальных целях и стратегических задачах развития Российской Федерации на период до 2024 года» // КонсультантПлюс. [Электронный ресурc]. URL: http://www.consultant. ru/document/cons_doc_LAW_335693/ (дата обращения: 15.08.2021).

39. Anitei M., Veres C., Pisla A. Research on Challenges and Prospects of Digital Agriculture // Proceedings. 2020. № 63 (1). DOI:10.3390/proceedings2020063067

40. Bahn, R.A.; Yehya, A.A.K.; Zurayk, R. Digitalization for Sustainable Agri-Food Systems: Potential, Status, and Risks for the MENA Region // Sustainability. 2021. № 13. 3223. DOI: $10.3390 /$ su 13063223

41. Deichmann U. Will Digital Technologies Transform Agriculture in Developing Countries? Washington, DC: World Bank, 2016. 30 p.

42. German sustainable development strategy // The Federal Government. [Электронный ресурc]. URL: https://www.bundesregierung.de/resource/blob/974430/1940716/6 a4acf041217d39bac6a81cce971381f/2021-07-26-gsds-en-data.pdf?download=1 (дата обращения: 20.06.2021).

43. Hrustek L. Sustainability Driven by Agriculture through Digital Transformation. Sustainability. 2020. 12. 8596. DOI: $10.3390 /$ su12208596

44. Lybbert T., Sumner D. Agricultural Technologies for Climate Change Mitigation and Adaptation in Developing Countries: Policy Options for Innovation and Technology Diffusion / International Centre for Trade and Sustainable Development. 2010. № 6.

45. U.S. agriculture innovation strategy: a directional vision for research / USDA Science, 2021. 30 p.

46. Yurina N. The digitalization of agriculture as a priority direction of Russian economic's development // The European Proceedings of Social \& Behavioural Sciences. 2019. P. 701-710.

\section{Транслитерация по ГОСТ 7.79-2000 Система Б}

1. Altukhov A.I., Dudin M.N., Anishhenko A.N. TSifrovaya transformatsiya kak tekhnologicheskij proryv i perekhod na novyj uroven' razvitiya agropromyshlennogo sektora Rossii // Prodovol'stvennaya politika i bezopasnost'. 2020. Tom 7. № 2. S. 81-96.

2. Analiticheskij tsentr Minsel'khoza Rossii podpisal soglashenie o sotrudnichestve s regionami strany // Ministerstvo sel'skogo khozyajstva Rossijskoj Federatsii. [EHlektronnyj resurs]. URL: https://mcx.gov.ru/press-service/news/analiticheskiy-tsentr-minselkhoza-rossii-podpisal-soglashenie-o-sotrudnichestve-s-15-regionami-stran/ (data obrashheniya: 9.08.2021 g.).

3. Antonova N.A. Vliyanie sovremennoj federal'noj politiki na razvitie ehksportnogo potentsiala sel'skogo khozyajstva Dal'nego Vostoka // Regionalistika. 2018. № 4. S. 24-34.

4. Arkhipov A.G., Kosogor S.N., Bulanov N.A. Metodicheskie rekomendatsii po razrabotke regional'nogo indeksa tsifrovizatsii agropromyshlennogo kompleksa. M.: Ministerstvo sel'skogo khozyajstva, 2019. 116 s. 
5. Arykbaev R.K., Ajtpaeva A.A. Upravlenie tsifrovizatsiej APK i obespechenie prodovol'stvennoj bezopasnosti RF v sovremennykh usloviyakh // Vliyanie novoj geopoliticheskoj real'nosti na gosudarstvennoe upravlenie i razvitie Rossijskoj Federatsii / pod red. Z.A. Saidova. Groznyj: Izdatel'stvo CHGU, 2019. S. 52-56.

6. Ashinova M.K., Mokrushin A.A., CHinazirova S.K., Kostenko R.V. TSifrovaya transformatsiya otrasli sel'skogo khozyajstva Rossijskoj Federatsii // Novye tekhnologii / New technologies. 2019. № 4. S. 209-220.

7. Vartanova M.L., Drobot E.V. Perspektivy tsifrovizatsii sel'skogo khozyajstva kak prioritetnogo napravleniya importozameshheniya // EHkonomicheskie otnosheniya. 2018. Tom 8. № 1. S. 1-18.

8. V polovine regionov Rossii otmechaetsya polozhitel'naya dinamika tsifrovizatsii APK // Ministerstvo sel'skogo khozyajstva Rossijskoj Federatsii. [EHlektronnyj resurs]. URL: https://mcx.gov.ru/press-service/news/v-polovine-regionov-rossii-otmechaetsya-polozhitelnaya-dinamika-tsifrovizatsii-apk/ (data obrashheniya: 5.08.2021)

9. V Rossel'khozbanke nazvali naibolee gotovye k tsifrovomu APK regiony // RIA Novosti. 19.06.2020. [EHlektronnyj resurs]. URL: https://ria.ru/20200619/1573163101.html (data obrashheniya: 1.08.2021).

10. Gospodderzhka fermerov perekhodit na tsifru // Somnews. 1.09.2020. [EHlektronnyj resurs]. URL:https://www.comnews.ru/content/208865/2020-09-01/2020-w36/gospodderzhka-fermerov-perekhodit-cifru (data obrashheniya: 12.08.2021).

11. Zueva N.S. Pereselencheskaya politika rossijskogo pravitel'stva na Dal'nem Vostoke v period stolypinskikh reform. Dis.... kand. ist. nauk. M.: Moskovskij pedagogicheskij gosudarstvennyj universitet, 2016. $351 \mathrm{~s}$.

12. Krylatykh EH.N., Protsenko O.D., Dudin M.N. Aktual'nye voprosy obespecheniya prodovol'stvennoj bezopasnosti Rossii v usloviyakh global'noj tsifrovizatsii // Prodovol'stvennaya politika i bezopasnost'. 2020. Tom 7. № 1. S. 19-38.

13. Kurdyumov A.V. Reindustrializatsiya i tsifrovizatsiya APK Rossii: osnova obespecheniya prodovol'stvennoj bezopasnosti // Novaya industrializatsiya Rossii: ehkonomika - nauka - chelovek - prirodopol'zovanie: sb. nauch. tr. VI Ural'skikh nauchnykh chtenij professorov i doktorantov. Ekaterinburg: Ural'skij gosudarstvennyj ehkonomicheskij universitet, 2019. S. 65-70.

14. Morozov B.N. Razvitie sel'skogo khozyajstva, promyshlennosti i promyslov na Dal'nem Vostoke Rossii v kontse XIX - nachale XX vekov. Avtoreferat dis.... d-ra. ist. nauk. Nizhnij Novgorod, 1997. 61 s.

15. Na Dal'nem Vostoke zapushhena pervaya sistema tsifrovogo upravleniya molochnoj fermoj na osnove IoT datchikov ot MTS // MTS. 4.06.2020. [EHlektronnyj resurs]. URL: $\quad$ https://khv.mts.ru/about/media-centr/soobshheniya-kompanii/novosti-mts-v-regione/2020-06-04/na-dalnem-vostoke-zapushhena-pervaya-sistema-cifrovogo-upravleniya-molochnoj-fermoj-na-osnove-iot-datchikov-ot-mts (data obrashheniya: 12.08.2021).

16. Natsional'nyj plan razvitiya sel'skokhozyajstvennykh i tekhnologicheskikh parkov (2018-2025) // EHntsiklopediya Baidu. [EHlektronnyj resurs]. URL: https://goo.su/0zAc (data obrashheniya: 17.07.2021).

17. O dolgosrochnoj strategii razvitiya agropromyshlennogo kompleksa Rossijskoj Federatsii / Sovet Federatsii RF. Analiticheskij vestnik. 2018. №10 (699).

18. Postanovlenie Pravitel'stva RF ot 02.06.2008 № 418 (red. ot 19.06.2021) «O Ministerstve tsifrovogo razvitiya, svyazi i massovykh kommunikatsij Rossijskoj Federatsii» // Konsul'tantPlyus. [EHlektronnyj resurs]. URL: http://www.consultant.ru/document/cons_ doc_LAW_77387/ (data obrashheniya: 26.06.2021).

19. Postanovlenie Pravitel'stva RF ot 07.09.2018 № 1065 (red. ot 24.07.2021) "O Pravitel'stvennoj komissii po tsifrovomu razvitiyu, ispol'zovaniyu informatsionnykh tekhnologij dlya uluchsheniya kachestva zhizni i uslovij vedeniya predprinimatel'skoj deyatel'nosti" (vmeste s "Polozheniem o Pravitel'stvennoj komissii po tsifrovomu razvitiyu, ispol'zovaniyu informatsionnykh tekhnologij dlya uluchsheniya kachestva zhizni i uslovij vedeniya predprinimatel'skoj deyatel'nosti") // Konsul'tantPlyus. [EHlektronnyj resurs]. URL: http://www.consultant.ru/document/cons_doc_LAW_306391/ (data obrashheniya: 24.07.2021).

20. Poslanie Prezidenta RF Federal'nomu Sobraniyu ot 21.04.2021// Konsul'tantPlyus. [EHlektronnyj resurs]. URL: http://www.consultant.ru/document/cons_doc_ LAW_382666/ (data obrashheniya: 27.07.2021).

21. Poslanie Prezidenta RF Federal'nomu Sobraniyu ot 20.02.2019 // Konsul'tantPlyus. [EHlektronnyj resurs]. URL: http://www.consultant.ru/document/cons_doc_ LAW_318543/ (data obrashheniya: 27.07.2021).

$2 \overline{2}$. Potenko T.A., Emel'yanov A.N. EHksportnyj potentsial sel'skogo khozyajstva Dal'nego Vostoka Rossii // Dal'nevostochnyj agrarnyj vestnik. 2018. №1 (45). S. 125-133.

23. Pochti 600 molochnykh proizvoditelej chestny s potrebitelem v Primor'e // CHestnyj znak. 5.08.2021. [EHlektronnyj resurs]. URL: https://xn--80ajghhoc2aj1c8b.xn--p1ai/ info/smi_o_nas/pochti-600-molochnykh-proizvoditeley-chestny-s-potrebitelem-v-primore/ (data obrashheniya: 12.08.2021). 
24. Rasporyazhenie Pravitel'stva RF ot 12.04.2020 N 993-r «Ob utverzhdenii Strategii razvitiya agropromyshlennogo i rybokhozyajstvennogo kompleksov Rossijskoj Federatsii na period do 2030 goda" // Konsul'tantPlyus. [EHlektronnyj resurs]. URL: http://www. consultant.ru/document/cons_doc_LAW_350437/(data obrashheniya: 25.07.2021).

25. "Rostelekom» tsifroviziruet predpriyatiya agrokholdinga «Agrotek» // Rostelekom. 26.01.2021. [EHlektronnyj resurs]. URL:https://www.company.rt.ru/press/news/d457947/ (data obrashheniya: 12.08.2021).

26. Svoyo, rodnoe: [sajt]. URL: https://svoe-rodnoe.ru/

27. Stasyukevich S.M. Zemel'naya politika sovetskoj vlasti i zemleustrojstvo na Dal'nem Vostoke v 1920-kh gg. // Ojkumena. Regionovedcheskie issledovaniya. 2017. № 1(40). S. 90-103.

28. Stepan'ko A.A. Agropotentsial Dal'nego Vostoka Rossii i ego ispol'zovanie v usloviyakh prodovol'stvennykh sanktsij // Vestnik AGAU. 2017. № 10 (156). S. 71-76.

29. Strategiya tsifrovoj transformatsii sel'skogo khozyajstva - «Moya tsifrovaya ferma» ili "Privet, Ferma!» (utv. Pravitel'stvennoj komissiej po tsifrovomu razvitiyu, ispol'zovaniyu informatsionnykh tekhnologij dlya uluchsheniya kachestva zhizni i uslovij vedeniya predprinimatel'skoj deyatel'nosti (protokol ot 25.06.2021 № 20 // Konsul'tantPlyus. [EHlektronnyj resurs]. URL: http://www.consultant.ru/document/cons_doc_LAW_390530/ (data obrashheniya: 28.06.2021).

30. Strel'tsova T.A. Istoriya razvitiya sel'skogo khozyajstva Dal'nego Vostoka (seredina 1940-kh - konets 1980-kh gg.) // Dal'nevostochnyj agrarnyj vestnik. 2008. №2 (6). S. 89-93.

31. Sukhomirov G.I. Tekhnologicheskaya modernizatsiya sel'skogo khozyajstva Dal'nego Vostoka // Problemy razvitiya territorii. 2014. №5 (73). S. 123-135.

32. Sukhomirov G.I. Problema samoobespecheniya sel'skokhozyajstvennymi produktami v regionakh Dal'nevostochnogo federal'nogo okruga // Problemy razvitiya territorii. 2017. №1 (87). S. 173-186.

33. Tekushhee razvitie proektov v sfere tsifrovoj ehkonomiki v regionakh Rossii // Analiticheskij tsentr pri pravitel'stve Rossijskoj Federatsii. [EHlektronnyj resurs]. URL: https://ac.gov.ru/archive/files/publication/a/23299.pdf (data obrashheniya: 20.07.2021).

34. Tele2 razvivaet «umnuyu» marikul'turu na Dal'nem Vostoke// Gazeta.ru. 6.06.2019. [EHlektronnyj resurs]. URL: https://www.gazeta.ru/tech/news/2019/06/06/n_13061359. shtml (data obrashheniya: 12.08.2021).

35. Trendov N.M., Varas S., TSzehn M. TSifrovye tekhnologii na sluzhbe sel'skogo khozyajstva i sel'skikh rajonov. Spravochnyj dokument. Rim: Prodovol'stvennaya i sel'skokhozyajstvennaya organizatsiya Ob"edinennykh Natsij, 2019. $26 \mathrm{~s}$.

36. Truflyak E.V. Rejting regionov po ispol'zovaniyu ehlementov tochnogo sel'skogo khozyajstva. Krasnodar: KubGAU, 2020. 37 s.

37. Ukaz Prezidenta Rossijskoj Federatsii ot 21 iyulya 2020 g. № 474 «O natsional'nykh tselyakh razvitiya Rossijskoj Federatsii na period do 2030 goda» // Rossijskaya gazeta. 22.07.2020. [EHlektronnyj resurs]. URL: https://rg.ru/2020/07/22/ukaz-dok.html (data obrashheniya: 14.08.2021).

38. Ukaz Prezidenta Rossijskoj Federatsii ot 7 maya 2018 g. № 204 «O natsional'nykh tselyakh i strategicheskikh zadachakh razvitiya Rossijskoj Federatsii na period do 2024 goda" // Konsul'tantPlyus. [EHlektronnyj resurs]. URL: http://www.consultant.ru/document/cons_doc_LAW_335693/ (data obrashheniya: 15.08.2021).

39. Anitei M., Veres C., Pisla A. Research on Challenges and Prospects of Digital Agriculture // Proceedings. 2020. № 63 (1). DOI:10.3390/proceedings2020063067

40. Bahn, R.A.; Yehya, A.A.K.; Zurayk, R. Digitalization for Sustainable Agri-Food Systems: Potential, Status, and Risks for the MENA Region // Sustainability. 2021. № 13. 3223. DOI: $10.3390 /$ su 13063223

41. Deichmann U. Will Digital Technologies Transform Agriculture in Developing Countries? Washington, DC: World Bank, 2016. 30 p.

42. German sustainable development strategy // The Federal Government. [EHlektronnyj resurs]. URL: https://www.bundesregierung.de/resource/ blob/974430/1940716/6a4acf041217d39bac6a81cce971381f/2021-07-26-gsds-en-data.pdf?download=1 (data obrashheniya: 20.06.2021).

43. Hrustek L. Sustainability Driven by Agriculture through Digital Transformation. Sustainability. 2020. 12. 8596. DOI: 10.3390/su12208596

44. Lybbert T., Sumner D. Agricultural Technologies for Climate Change Mitigation and Adaptation in Developing Countries: Policy Options for Innovation and Technology Diffusion / International Centre for Trade and Sustainable Development. 2010. № 6 .

45. U.S. agriculture innovation strategy: a directional vision for research / USDA Science, 2021. $30 \mathrm{p}$.

46. Yurina N. The digitalization of agriculture as a priority direction of Russian economic's development // The European Proceedings of Social \& Behavioural Sciences. 2019. P. 701-710. 
Склярова С. А. Цифровизация агропромышленного комплекса Дальнего Востока, как один из приоритетов государственной политики.

Российский Дальний Восток является значимым регионом в развитии всей страны, и, в частности, в рамках современной повестки о переходе к более экологичному сельскохозяйственному производству. Цифровизация АПК на Дальнем Востоке является ключевым инструментом, способным оказать сильное влияние на развитие экспорта экологически чистого продовольствия, повышение уровня жизни. В статье обосновывается необходимость цифровизации агропромышленного комплекса субъектов Дальнего Востока и определения этого направления экономического развития как одного из приоритетов государственной политики. На основе обобщения теоретических исследований российских и зарубежных авторов выявлены и систематизированы проблемы цифровизации сельского хозяйства в разных странах. Проведён анализ уровня цифровизации АПК Дальнего Востока с использованием как официальных, так и неофициальных источников информации. В заключении сделан обзор некоторых значимых инициатив и проектов в сфере цифровизации агропромышленного комплекса на Дальнем Востоке, а также определены сдерживающие данные процессы фракторы.

Ключевые слова: государственная политика, иифровизация, иифровая траснфорлация, агропромышленный колплекс, сельское хозяйство, Дальний Восток

Sklyarova S. A. Digitalization of the agro-industrial complex of the Far East as one of the priorities of state policy.

The Far East is a significant region in the development of the entire country, and, in particular, within the framework of the modern agenda for the transition to more environmentally friendly agricultural production and the development of non-resource export industries. The digitalization of the agro-industrial complex in the Far East is a key tool that can have a strong impact on the development of the export of environmentally friendly food, improve the standard of living in the region, etc. Based on the generalization of theoretical studies of Russian and foreign authors, the problems of digitalization of agriculture in different countries are identified and systematized. The analysis of the level of digitalization of the agro-industrial complex of the Far East using both official and unofficial sources of information. In conclusion, an overview of some significant initiatives and projects in the field of digitalization of the agro-industrial complex in the Far East is made, as well as factors constraining these processes are identified.

Key words: government policy, digitalization, digital transformation, agroindustrial complex, agriculture, the Far East

Для цитирования: Склярова С. А. Цифровизация агропромышленного комплекса Дальнего Востока, как один из приоритетов государственной политики // Ойкумена. Регионоведческие исследования. 2021. № 4. C. 24-38. DOI: 10.24866/1998-6785/2021-4/24-38

For citation: Sklyarova S. A. Digitalization of the agro-industrial complex of the Far East as one of the priorities of state policy // Ojkumena. Regional researches. 2021. № 4. P. 24-38. DOI: $10.24866 / 1998-6785 / 2021-4 / 24-38$ 